\title{
A KÉSZSÉGEK ÉS AZ OKTATÁS KÖVETELMÉNYRENDSZERE A TUDÁSALAPÚ TÁRSADALOMBAN
}

\section{SKILLS AND EDUCATION IN KNOWLEDGE-BASED SOCIETY}

\author{
Varga Júlia \\ kandidátus, tudományos fömunkatárs, MTA Közgazdaság- és Regionális Tudományi Kutatóközpont Közgazdaság-tudományi Intézet \\ varga.julia@krtk.mta.hu
}

\section{ÖSSZEFOGLALÁS}

A cikk az MTA Gazdaság- és Jogtudományok Osztálya 2017. évi tudományos ülésén elhangzott előadás főbb gondolatait foglalja össze. Az előadás azt mutatta be, hogy az új (digitális) ipari forradalom nyomán az oktatási rendszer milyen készségek, ismeretek megerősítésével, átadásával járulhat hozzá ahhoz, hogy az oktatási rendszerből kikerültek sikeresek legyenek a munkaerőpiacon, hogy boldogulni tudjanak későbbi életükben, valamint hogy a magyar oktatási rendszer mennyiben felel meg ezeknek a követelményeknek, és hogy az oktatás átalakítását célzó reformok várhatóan milyen hatással lesznek e készségek és ismeretek alakulására.

\section{ABSTRACT}

The article summarises my presentation's main points presented at the 2017 Scientific Meeting of the Scientific Section of Economics and Law of the Hungarian Academy of Sciences. The central question of the presentation was, how the new (digital) industrial revolution has changed the necessary skills and competencies that help graduates to become successful on the labour market just after graduation and later on. It also investigated if the Hungarian education system is capable to meet these challenges and if the recent educational reforms in Hungary will help to strengthen the necessary skills and competencies of graduates.

Kulcsszavak: digitális forradalom, oktatás, munkaerőpiac, oktatási reform

Keywords: digital revolution, education, labour market, educational reform

Bár korábban komoly viták voltak a növekedést vizsgáló közgazdászok között arról a kérdésről, hogy az oktatás és a gazdasági növekedés közötti kapcsolatban mi a kauzalitás iránya, mára számos tanulmány egyértelmü bizonyítékokkal támasztotta alá (például: Hanushek-Woessemann, 2009, 2015; Fägerlind-Saha, 2016), hogy az oktatás, az iskolázottság hatással van a növekedésre, ha az iskolázottságot nem a korábban általánosan használt, befejezett osztályszámmal, 
hanem az oktatás eredményességével, a népesség vagy a fiatalok nemzetközi teszteredményeivel mérjük. A befejezett osztályszám tökéletlen mércéje volt a népesség iskolázottsága nemzetközi összehasonlításának, hiszen az országok különböznek az iskolaévek hosszában, az oktatás tartalmában, minőségében és eredményességében. Korábban azért a befejezett osztályszám átlagával vagy a különböző iskolai fokozatokat legmagasabb iskolai végzettségként elért népesség arányával mérte a népesség iskolázottságát, egy adott ország emberi tőkeállományát a legtöbb vizsgálat, mivel ez volt az egyetlen, nemzetközileg összehasonlítható adat. Az elmúlt évtizedekben viszont rendszeressé váltak a nemzetközi kompetenciamérések (például a tizenöt évesek körében felvett PISA ${ }^{1}$, vagy a felnőtt népesség körében felvett IALS ${ }^{2}$ vagy PIAAC ${ }^{3}$ stb.), melyek arról gyüjtenek információt, hogy milyen a népesség képesség- és készségszintje. Ezeknek a teszteknek a többsége nem azt méri, hogy milyen lexikális ismeretekkel rendelkeznek a tesztek kitöltői, hanem azoknak a készségeknek, kompetenciáknak a mérésére irányulnak, azoknak az alapkészségeknek a meglétét és szintjét mérik, melyek az utóbbi évtizedekben egyre gyorsuló ütemben értékelödtek fel a munkaerőpiacon.

Az elmúlt évtizedekben a „képzettségtorzított technológiai váltás” (skill-biased tecnological change) nyomán alapvetően átalakultak a különböző munkafeladatok arányai a fejlett országokban. Az 1. ábra az Egyesült Államokra vonatkozóan mutatja be a munkafeladatok arányának változását 1960 és 2009 között. A munkafeladatokat azok ismerettartalma alapján öt csoportba sorolták be az elemzés készítői. (1) Az „új információ alkalmazása” csoport feladatai közé azokat a feladatokat sorolták, melyek korábban ismeretlen információ megkeresésére, összegyűjtésére és alkalmazására irányulnak. Ilyen feladat lehet például, ha egy hotel menedzsmentje eldönti, hogy érdemes-e légkondicionálót beszerezni. (2) A „strukturálatlan problémamegoldás” csoportba azokat a feladatokat sorolták, melyek egyszerü szabálykövetéssel nem megoldhatóak. Ilyen feladat például egy nem tipikus tüneteket mutató beteg esetében a diagnózis felállítása. (3) A „rutin kognitív feladatok” csoportjába olyan szellemi feladatok kerültek, melyek egyszerü deduktív és induktív szabályokkal megoldhatóak. Ilyen például az adóbevallás elkészítése. (4) A „rutin manuális feladatok” azok a manuális feladatok, melyek szintén egyszerü szabálykövetéssel megoldhatóak. (5) Végül, a „,nem rutin manuális feladatok” olyan fizikai feladatok, amelyeket nem lehet szabályokkal jól leírni, mert vagy finom optikai felismerés, vagy finom izomkontroll kell hozzá. Ilyen feladat például a kamionvezetés.

Az ábrán látjuk, hogy az 1970-es évek közepétől fogva folyamatosan és meredeken nőtt a strukturálatlan problémamegoldás és az új információ alkalmazásának

\footnotetext{
${ }^{1}$ Programme for International Student Assessment

2 International Adult Literacy Survey

${ }^{3}$ Programme for the International Assessment of Adult Competencies
} 
aránya a munkafeladatokon belül, és ezzel egyidejüleg csökkent a rutin manuális feladatok és a rutin kognitív feladatok aránya, miközben a nem rutin manuális feladatok aránya az 1990-es évek elejéig csökkent, majd állandósult, sőt kismértékben nőtt is. Az átrendeződés a munkafeladatok arányában több okra vezethető vissza. Egyrészt arra, hogy változik a foglalkoztatás foglalkozások szerinti öszszetétele, másrészt változik a foglalkozások feladattartalma. Ugyanazon foglalkozás gyakorlásához is más készségek, ismeretek szükségesek ma már a technológia változása és az automatizáció és digitalizáció következtében. Röviden, a foglalkoztatáshoz szükséges alapkészségek megváltoztak, a rutin készségek leértékelődtek. Ez a folyamat nem állt meg az utóbbi években sem, évről évre nő azoknak a feladatoknak a száma, melyeket digitalizálnak, automatizálnak. A számítógépek jobban, gyorsabban és olcsóbban tudják követni az utasításokat, mint az emberek, ezért tovább csökken a kereslet a rutin kognitív és manuális készségek iránt, és nő a problémamegoldó készségek iránt. A munkaerőpiacon a technológiai váltás eredményeként bekövetkezett munkafeladat arányváltozások következményeként a képzetlen munkaerő iránti kereslet és relatív árának csökkenésére, és a magasan képzett munkaerő iránti kereslet növekedésére lehet számítani.

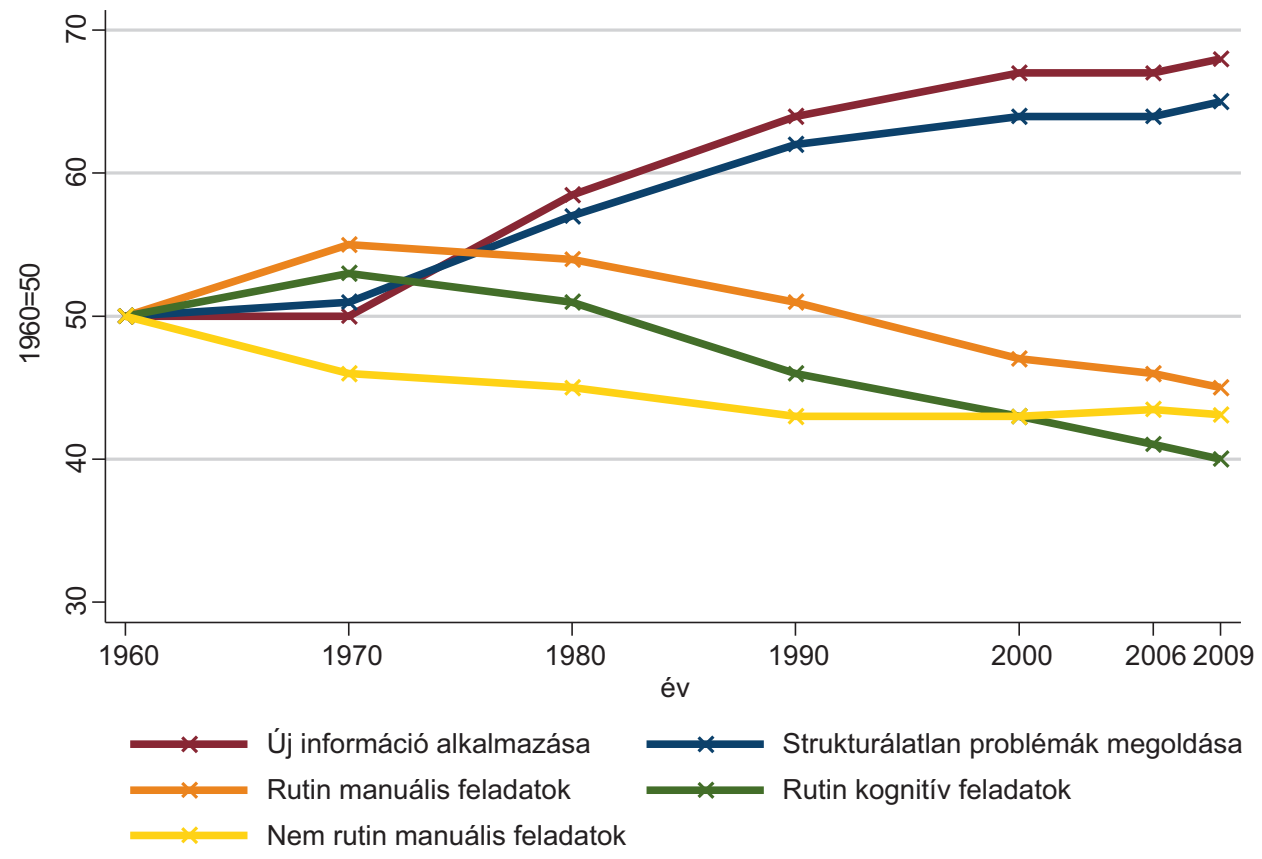

1. ábra. A munkafeladatok arányának változása az USA gazdaságában 1960-2009 között Forrás: Levy-Murnane, 2013 
Ez a folyamat egyes szakmák teljes, mások részleges automatizációja mellett várhatóan a munkahelyek egy nagy hányadának megszünését fogja eredményezni. Az utóbbi években számos tanulmány megpróbálta előre jelezni, hogy mekkora az automatizációnak kitett foglalkozások aránya. Carl Benedikt Frey és Michael A. Osborne (2013) becslései szerint az Egyesült Államokban a foglalkoztatottak 47\%-a dolgozik olyan munkakörben, melyet a következő két évtizedben automatizálni fognak. A McKinsey Global Institute tanulmánya (Manyika et al., 2017) arra számít, hogy a következő évtizedekben az állások 45\%-a fog megszünni. A World Development Report (2016) becslései szerint az OECD-ben az állások 57\%-a szünik meg a következő két évtizedben. Ezek a tanulmányok azt feltételezték, hogy az automatizáció és digitalizáció nyomán teljes foglalkozások fognak megszünni. Más vizsgálatok (például Arntz et al., 2016) a foglalkozások feladattartalmának elemzése alapján próbáltak meg előrejelzéseket tenni. Eredményeik szerint a foglalkozások 9-12\%-a nagyon veszélyeztetett, és a következő évtizedben el fog tünni. A különböző országok munkahelyei eltérő mértékben vannak kitéve az automatizáció és digitalizáció miatti foglalkozásvesztés valószínüségének attól függően, hogy foglalkozási szerkezetükben mekkora mértékben vannak jelen a könnyen automatizálható feladatok. A 2. ábra az európai országokra vonatkozóan mutatja be, hogy foglalkozásaik mekkora hányada van kitéve az automatizáció és digitalizáció miatti megszünés veszélyének a Bruegel Kutatóközpont számításai szerint, a kalkuláció Frey és Osborne (2013) módszerére épült.

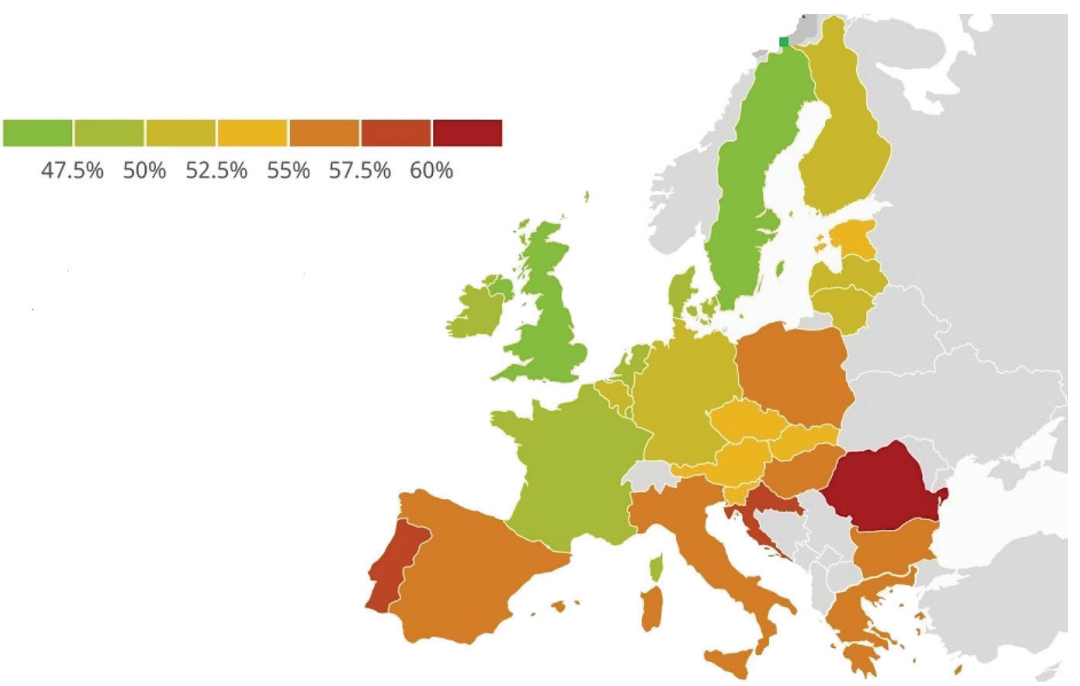

2. ábra. Azoknak az állásoknak az aránya, melyek munkafeladatai automatizálhatók, digitalizálhatók

Forrás: Bruegel számításai Frey és Osborne (2013) módszerére és az ILO Labour Force Survey 2012 adataira alapozva (URL1) 
Bár valamennyi országban igen magas a foglalkozások megszűnésének kockázata, azok az országok, amelyeknek foglalkozási szerkezetében a könnyebben automatizálható feladatok nagyobb arányt képviselnek, jobban érintettek. A foglalkozások megszünése mellett valószínüsíthető, hogy a korábbi komoly technológiai forradalmakhoz hasonlóan nemcsak foglalkozások fognak megszűnni, hanem új foglalkozások is keletkeznek majd. Egyes kalkulációk szerint a ma az iskolarendszerbe kerülő gyerekek 65\%-a olyan foglalkozásokban fog majd dolgozni, melyek ma még nem is léteznek (Davidson, 2011).

A munkafeladatok összetételében végbemenő nagyon komoly átalakulásoknak az a következménye az oktatási rendszerekre, hogy olyan jövőre kell felkészíteniük a diákokat, ami bizonytalan és nehezen jelezhető előre. Az oktatási rendszer a hosszú távú foglalkoztathatóság megalapozásával tud jól hozzájárulni az ország humán tőkeállománya növekedést segítő szintjének biztosításához és az egyének munkaerőpiaci boldogulásának megalapozásához. Azok a diákok, akik 2017-ben kerültek általános iskolába, 2076-ban fogják elérni a nyugdíjkorhatárt, a 2017ben középiskolába kerültek 2068-ban, a felsőoktatásba kerültek pedig 2062-ben. Egyre több kutatás mutat rá, hogy azok a tantervek, amelyek a könnyen automatizálható feladatokra és a speciális szakképzésre helyezik a hangsúlyt, nem készítik fel a diákokat a 21. századi technológiai változások felgyorsulásának következményeire.

A magyar oktatási rendszer mennyiségi mutatói az 1990 után bekövetkezett oktatási expanzió következtében javultak. A középfokúnál alacsonyabb végzettségüek aránya csökkent (2016-ban a huszonöt-harmincnégy évesek között 14\% volt, ami az EU-15 országok átlagánál, a 18,1 százaléknál még valamivel kedvezőbb is). A középfokú végzettségüek aránya nőtt (2016-ban a huszonötharmincnégy évesek között 53,8 százalék volt, szemben az EU-15 átlagosan 43,5 százalékával). Ugyancsak növekedett a középfokú szakképzettséget szerzettek között az érettségivel rendelkezők aránya (Hajdu et al., 2015), ami szintén kedvező fejlemény, mivel ezeknek a diákoknak jobbak az alapkészségeik, mint az érettségit nem szerzett, középfokú szakképzettséget szerzőké, amit a magyar munkaerőpiac jelenleg is honorál: nagyobb foglalkoztatási és kisebb állásvesztési esélyekkel, valamint magasabb keresetekkel (lásd Hajdu et al., 2015). A felsőfokú végzettségủek aránya nőtt (2016-ban a huszonöt-harmincnégy évesek között 32,1 százalék volt, ami elmaradt az EU-15 átlagától, a 38,4 százaléktól). A mennyiségi mutatókat tekintve tehát a felsőfokú végzettségúek arányában figyelhető meg lemaradás. Az oktatás minősége, eredményessége, a korábban bemutatott, a munkaerőpiacon felértékelődő készségek tekintetében viszont nem kedvező a helyzet, és javulás helyett egyelöre romló tendenciák mutatkoznak. Így az utóbbi években romlottak a magyar PISA-eredmények (Csapó et al., 2014), de más humántőkeindexek is, például a World Economic Forum humántőke indexe. Az oktatási rendszert érintő, utóbbi években meg- 
figyelhetô reformok pedig komoly aggályokat vetnek fel, hogy az átalakítások milyen hatással lesznek a végzettek azon alapkészségeire, melyek felértékelödését bemutattam.

Az oktatási reformok nyomán a szakközépiskola (korábbi néven szakiskola) képzési ideje négy év helyett három évre csökkent, és a közismereti tárgyak tanítási ideje jelentősen csökkent. A szakgimnáziumokban (korábbi néven szakközépiskola) ugyancsak csökkent a közismereti tárgyak tanítási ideje, ami kiemelten a természettudományi tárgyak tanítási idejének csökkenésével járt. A szakgimnáziumi tanulók a 9. évfolyamon összevont természettudományi tárgyat tanulnak, majd a 10-12. évfolyamon már csak egyetlen, ,a szakmához szükséges" természettudományi tárgyat. Az 1. táblázatban azt foglaltam össze, hogy a reformok nyomán hogyan változott a közismereti tárgyak óraszáma a képzési idő végéig a középfokú szakmai képzést is nyújtó iskolákban.

1. táblázat. Közismereti órák száma (testnevelés nélkül) a teljes tanulmányi idő alatt a reformok elött és után

\begin{tabular}{|l|c|c|}
\hline \multicolumn{1}{|c|}{ Tanév } & $\mathbf{2 0 0 3 / 2 0 0 4}$ & $\mathbf{2 0 1 6 / 2 0 1 7}$ \\
\hline Szakközépiskola (korábban szakiskola) & 832 & 676 \\
Szakgimnázium (korábban szakközépiskola) & 2754 & 2390 \\
\hline
\end{tabular}

Forrás: Magyar Közlöny 2003/43/II. szám és 22/2016. (VIII. 25.) EMMI rendelet

A jelenlegi szakközépiskolákban a diákok húsz százalékkal kevesebb közismereti képzést kapnak tanulmányi idejük végéig, mint a reform elött, a jelenlegi szakgimnáziumokban pedig tizenöt százalékkal kevesebb a közismereti órák száma a teljes tanulmányi idő alatt, mint korábban. Ez azért is aggályos, mivel a magyar diákok már az általános iskolai képzési szakaszban, tehát a tanulók általános készségeit elöször megalapozó oktatási szinten is kevesebb közismereti órát kapnak, mint például a magyar reformok átalakítását indokló gondolatmenetek egyik példaországaként felhozott Németország diákjai. A 2. táblázat azt mutatja be, hogy mennyit tanult egy magyar és egy német diák addig az időpontig, amíg belép a középfokú szakképzésbe.

A német diákok tehát több közismereti képzésben részesülnek addig, amíg belépnek a középfokú szakképzésbe, mint egy magyar diák mire befejezi a középfokú szakképzést. Ha csak a közismereti képzés mennyiségét tekintjük, akkor is azt látjuk, hogy a magyar oktatási rendszer átalakításai várhatóan az alapkészségek romlását fogják eredményezni, ami kétségessé teszi, hogy a tanulók majd menyire fognak tudni megfelelni a munkaerőpiacon történő folyamatos átalakulásokhoz való alkalmazkodásnak. 
2. táblázat. A középfokú szakképzésbe belépő magyar és német diákok megelőző közismereti képzése (2013/2014-es tanév)

\begin{tabular}{|l|c|c|}
\hline & Németország & Magyarország \\
\hline Az alsó- és alsó középfokú oktatás hossza (év) & 9 vagy $10^{*}$ & 8 \\
\hline Egy tanévre jutó tanítási órák száma & 795 & 719 \\
$\begin{array}{l}\text { Az alsó középfokú oktatás befejezéséig kapott } \\
\text { közismereti képzés mennyisége (tanítási órák száma) }\end{array}$ & $7155^{*}$ vagy 7950 & 5742 \\
\hline \hline
\end{tabular}

*Tartománytól függően

Forrás: Hajdu et al., 2015

Az iskolarendszerben végzettek a belépést követően még több mint negyven évet fognak eltölteni a munkaerőpiacon. Azt, hogy későbbi életpályájuk során mi lesz velük, szükség lesz-e a szaktudásukra, vagy nem, a technológia csak korlátozottan előrelátható változásaitól függ. A technológiai változások felgyorsulása fokozott ütemben tesz feleslegessé bizonyos szakmákat, más szakmáknak a tartalmát pedig teljesen megváltoztathatja. Az iskolarendszerből kikerülők későbbi foglalkoztatási esélyei ezért azon múlnak, hogy át tudják-e képezni magukat, tudnak-e új szakmát elsajátítani, vagy képesek-e követni saját szakmájuk tartalmi változásait. Mindez pedig attól függ, hogy a végzettek képesek-e elsajátítani azokat az új készségeket, amelyeket a változások megkövetelnek, be tudnak-e kapcsolódni a felnőttképzésbe, az „élethosszig tartó tanulásba”, hogy milyenek alapkészségeik.

\section{IRODALOM}

Arntz, M. - Gregory, T. - Zierahn, U. (2016): The Risk of Automation for Jobs in OECD Countries. OECD Social, Employment and Migration Working Papers No. 189. DOI: 10.1787/5jlz9h56dvq7-en https://goo.gl/ZxWeov

Csapó B. - Fejes J. B. - Kinyó L. - Tóth E. (2014): Az iskolai teljesítmények alakulása Magyarországon nemzetközi összehasonlításban. In: Kolosi T. - Tóth István Gy. (szerk.): Társadalmi Riport 2014. Budapest: TÁRKI, 110-136. http://www.tarki.hu/adatbank-h/kutjel/pdf/b327.pdf

Davidson, C. N. (2011): Now You See It: How Technology and Brain Science Will Transform Schools and Business for the $21^{\text {st }}$ Century. Penguin Books

Fägerlind, I. - Saha, L. J. (2016): Education and National Development: A Comparative Perspective. Elsevier

Frey, C. B. - Osborne, M. A. (2013): The Future of Employment: How Susceptible Are Jobs to Computarisation. Working Paper. Oxford Martin Programme on Technology and Employment. Oxford: Oxford Martin School, http://www.oxfordmartin.ox.ac.uk/downloads/academic/future-of-employment.pdf 
Hajdu T. - Hermann Z.- Horn D. et al. (2015): Az érettségi védelmében. (Budapesti Munkagazdasági Füzetek) BWP 2015/1. MTA KRTK KI-BCE Emberi Erőforrások Tanszék, http://www. econ.core.hu/file/download/bwp/bwp1501.pdf

Hanushek, E. A. - Woessmann, L. (2009): Do Better Schools Lead to More Growth? Cognitive Skills, Economic Outcomes, and Causation. Working Paper No. 14633. Cambridge, MA: National Bureau of Economic Research, DOI: 10.3386/w14633 http://www.nber.org/papers/w14633

Hanushek, E. A. - Woessmann, L. (2015): The Knowledge Capital of Nations: Education and the Economics of Growth. Cambridge, MA: MIT Press

Levy, F. - Murnane, R. J. (2013): Dancing with Robots. Human Skills for Computerized Work. Washington, DC: Third Way NEXT, http://s3.amazonaws.com/content.thirdway.org/publishing/attachments/files/000/000/056/Dancing-With-Robots.pdf?1412360045

Manyika, J - Chui, M. - Miremadi, M. (2017): A Future that Works : Automation, Employment and Productivity. McKinsey \& Company, https://www.mckinsey.com/ /media/McKinsey/ Global\%20Themes/Digital\%20Disruption/Harnessing\%20automation\%20for\%20a\%20future\%20that\%20works/MGI-A-future-that-works_Full-report.ashx

World Development Report 2016. Digital Dividents. World Bank Group. 2016.

URL1: http://bruegel.org/2014/07/chart-of-the-week-54-of-eu-jobs-at-risk-of-computerisation 